\title{
Sympathy for the devil? A defence of EAP
}

\author{
Ken Hyland
}

\section{Introduction}

The ability to communicate in English is now essential to academic success for many students and researchers. Not only has the language established a fairly firm grip in higher education, particularly in the lives of post graduate students, but also in academic research, where careers are increasingly tied to an ability to publish in international journals. Countless students and academics around the world, therefore, must now gain fluency in the conventions of relatively 'standardized' versions of academic writing in English to understand their disciplines, to establish their careers or to successfully navigate their learning. English for Academic Purposes (EAP), and the teaching of academic writing in particular, has emerged to support this process. However, EAP, and its relationship to English language education more generally, is seen from a number of different perspectives, not all of which flatter the field. Among the more critical are that it is complicit in the relentless expansion of English which threatens indigenous academic registers, that it is a remedial 'service activity' on the periphery of university life, and that it imposes an imprisoning conformity to disciplinary values and native norms on second language writers.

While these views have their supporters, some of whom are teachers themselves, they are commonly presented without clear educational alternatives and levelled at EAP as if it were a monolithic political instrument, taught by unreflective instructors blindly resolved on enforcing orthodoxy. In this paper I respond to these views as a teacher with a long term personal involvement in EAP writing, arguing that while EAPs pragmatism leaves it open to criticism, these views are seriously reductive and ignore the variety of commitments, contexts and discourses that fall under the EAP umbrella. Indeed, I argue that EAP can play an important role in assisting students to unpack textual norms to take a more 
critical view of the academy. In this paper, then, I stake out my own position and argue for a more positive and pro-active view of EAP and the merits of the specialised teaching of writing.

\section{Academic written English: the new communicative competence?}

EAP is an approach to language education based on identifying the specific language features, discourse practices, and communicative skills of target academic groups, and which recognizes the subject-matter needs and expertise of learners (Hyland, 2006). It sees itself as sensitive to contexts of discourse and action, and seeks to develop research-based pedagogies to assist study, research or publication in English. While some of this research looks at the ways language relates to local contexts and practices (e.g. Paltridge et al, 2016; Swales, 1998), EAP is generally understood as a textoriented approach. Teachers try to identify the diversity of disciplinary discourses in the academy and encourage students to engage analytically with target discourses and develop a critical understanding of the contexts in which they are used (e.g. Macallister, 2016). It is, then, concerned with access through the acquisition of the means to achieve certain learner determined study or career goals.

This framework has received considerable impetus over the past 20 years to support the demand created by the emergence of English as the scholarly lingua franca and the cross-border movement of knowledge and people it has encouraged. Across Europe and Asia universities now offer English medium degrees and those in inner circle countries recruit large numbers of fee-paying international students. Accompanying this change, domestic policies in many English-speaking countries have reformed elitist higher education systems to increase the number of local eligible university entrants, providing better educated workers for the 'knowledge economy'. As a result, student populations have become increasingly diverse, creating new challenges to university teachers and students alike. Even if it were possible in the past to rely on the communicative readiness of school leavers for academic study, this linguistically, socially and culturally diverse body of students makes such 
assumptions extremely questionable. At more advanced levels, research students, and academics themselves, are increasingly expected to produce academic papers in English to graduate and publish. Central to the learning needs of all these individuals are the communicative competencies essential to success in their courses and careers.

Clearly, the communicative demands on these academic writers, students and professionals alike, go far beyond control of linguistic error or basic 'language proficiency'. There is now a considerable body of research, experience and practice which emphasises the heightened, complex, and highly diversified nature of communicative demands in these contexts. There is a growing awareness that students, including native speakers of English, have to take on new roles and engage with knowledge in new ways when they enter university (Lea \& Street, 1998). Students accounts, for example, reveal the formidable nature of the challenges involved in producing successful writing at university (e.g. Fan, 1989; Fox, 1994). They find that they need to write and read unfamiliar genres and that communication practices reflect different, disciplinary-oriented, ways of constructing knowledge and engaging in academic study. These experiences, moreover, have powerful influences on writers' understandings of their disciplines, their learning, and themselves (Hyland, 2012; Lillis, 2001).

In other words, EAP does not see students' writing difficulties as a linguistic deficit which can be topped up by piecemeal remediation in a few language classes, but as their attempts to acquire a new literacy and, more specifically, new discourse practices. Engagement in academic writing, as a student, teacher or researcher, involves new ways of behaving, interacting and thinking about the world. It is a social practice rather than a skill in that it is related both to what people do and to the wider social structures in which they do it. In the classroom, this shifts language teaching away from isolated written or spoken texts towards contextualised communicative genres and an increasing preoccupation with identifying strategies suitable for both native and non-native speakers of the target language. So 
EAP is driven by a similar impetus to Communicative Language Teaching back in the 1970s: to make the language purposeful by relating it to credible real-world outcomes. It is the discourses of disciplines which activates communicative goals.

\section{What's not to like?}

Well, plenty it seems. EAP writing instruction, like all educational initiatives, is ideologically situated. It takes as its main objective to empower learners by initiating them into the ways of making meanings that are valued in their target contexts, whether these contexts are undergraduate study, doctoral writing or academic publishing. This stance, however, has been criticized from three main viewpoints. First is the claim that EAP has been quiescent in accepting, and benefiting from, the expansion of English across the world, thus promoting the economic interests of big business and contributing to the erosion of indigenous academic registers. Second, critics argue that disciplinary outsiders are ill-equipped to provide students with specialist disciplinary discourses and should seek common ground among learners. Third, they contend that EAP accepts a set of (Anglo-American) dominant discourse norms and regards students as passive and accommodating, thereby failing to question the power relations which underlie these norms. I will summarize these positions below then go on to give my view on them.

\subsection{Feeding the Tyrannosaurus}

The first perspective concerns the narrow lens that EAP adopts towards its socio-political context and in particular its role in the unfettered spread of English to a dominant place in academic communication. This spread can be regarded either as essentially benign, a neutral lingua franca efficiently facilitating the free exchange of knowledge, or as a Tyrannosaurus Rex, 'a powerful carnivore gobbling up the other denizens of the academic linguistic grazing grounds' (Swales, 1997: 374). For many it is the latter, a Trojan horse of Anglophone values and economic interests perpetuating reliance, removing choice, and 
eroding linguistic diversity. But while EAP teachers and students "now collectively occupy global, interconnected spaces" (Morgan \& Ramanathan, 2005, p. 152), they have done little to question or arrest this growth.

While historical circumstances, largely the legacy of US and British colonialism and the expansion of a single market across the world, are responsible for this spread, critics argue that EAP has been complicit in it. Not only has EAP failed to address the global expansion of English, fuelling the loss of specialized registers in the interests of big business (e.g. Benesch, 2001; Pennycook, 1997), but profits from it by providing courses, curricula and materials to universities and students worldwide. Indeed, some critics have directly implicated English language teaching in US-led imperialism. Kumaravadivelu (2006), for example, has argued that it stands behind capitalist expansion while Edge (2004, p. 718) has claimed that ELT served to create conditions for the invasion of Iraq by facilitating 'the policies the tanks were sent in to impose'.

Less dramatically, the prevalence of English in academia is most obvious in publishing, where it is estimated that six million scholars in 17,000 universities across the world produce over 1.5 million peer reviewed articles each year in English (Bjork et al, 2009). Almost all Czech, Hungarian and South Korean journals indexed by the SCI are in English for example, while France, Austria, Germany and Spain publish 90\% of their journals in English (Bordens \& Gomez, 2004). Italian has declined significantly in academic publications (Giannoni, 2008) and Swedish has virtually disappeared altogether (Swales, 1997). Further afield, some 500 Japanese scientific journals publish in English and scientists in Brazil (Meneghini \& Packer, 2007) and Hong Kong (Li \& Flowerdew, 2009) rarely write in any other language. EAP has participated in this more directly, with countries as diverse as Malaysia (Hyland, 2015), France and Germany (Ammon \& McConnell, 2002) now offering Masters' programmes in 
English to attract overseas students. By providing curricula and teachers to support this spread, EAP is held to be part of the problem..

\subsection{Servicing the university}

The second perspective takes a very different line by questioning the value, or even the possibility, of EAP itself, at least in its more specific forms. Critics argue that the field's aspiration to identify and teach the discourse varieties and practices of different academic disciplines is both unrealistic and arrogant. It amounts to outsiders attempting to teach discourses they only superficially understand and so ending up conducting a prescriptive training exercise only vaguely relate to education.

One line of attack contends that EAP teachers are outsiders who lack the expertise, knowledge and self-assurance to understand and teach disciplinary discourses at all (e.g. Spack, 1988). This restricts instruction to general study skills and relegates EAP to a low-status service role simply supporting academic departments instead of developing its own body of subject knowledge and skills like legitimate disciplines. This leads to what Raimes (1991) called 'the butler's stance' on the part of EAP, which de-professionalizes teachers and marginalizes EAP units. Krashen (2011) similarly regards specific EAP as skill-building: simply describing academic language then teaching it directly, an activity Widdowson (1983) sees as a training exercise, a more restricted and mundane activity than education, which involves assisting learners to understand and cope with a wider range of needs rather than follow the furrow ploughed for them by an instructor. Such an approach is likely to produce unimaginative and formulaic essays and fail to prepare students for the unpredictable (Huckin, 2003).

Another key argument here is that EAP classes are likely to be a waste of time for all but the most advanced learners as students at lower levels of proficiency first need to acquire a good knowledge of general English. Language learning is said to be an incremental process of acquisition involving 
brick-by-brick development so that students must understand core forms before progressing onto more complex rhetorical practices. Because of this, EAP is urged to focus on generic skills such as paraphrasing, notetaking and skimming and scanning, and on register-level language features. Hutchison and Waters (1987:165), for example, claim that there are insufficient variations in the grammar, functions, or discourse structures of different disciplines to justify a subject-specific approach. This is based on what Bloor and Bloor (1986) call the common core hypothesis, or the idea that many features of English are found in nearly all varieties. In these views, then, if EAP can be useful at all, it must restrict its role to familiarising students with general study skills and language patterns transferable across the academy.

\subsection{Accommodating the machine}

A third position critiques EAP's crudely pragmatic goals in rhetorically preparing students for academic study or research, claiming that in doing so it inculcates a set of dominant discourse norms which reinforce conformity to an unexamined educational and social order. By teaching the conventions of academic discourse, EAP instructors are treating these conventions as essentially value-free and natural rather than the expression of power relations, so perpetuating institutional goals and beliefs.

EAP, then, is too ready to conflate the needs of students with those of the disciplines and so support a hidden curriculum reinforcing existing power relations and uncritically 'accommodating' learners to the requirements of their courses (e.g. Benesch, 2001; Pennycook, 1997, 2001). Benesch (2001, p. 41), in fact, refers to EAP's position as "political quietism", suggesting a degree of collusion in preserving the status quo by failing to contest wider issues such as the way higher education is funded, the design of curricula and the maintenance of hierarchical structures. Critical pedagogy, in other words, believes that the teaching of EAP is inextricably bound up with questions of power, 
ideology and social justice and the classroom is where students are prepared for their roles in a capitalist society.

From this standpoint, EAP is seen to view learners as passive recipients of knowledge, encouraging them to simply mimic expert practices rather than engage as active learners in questioning and understanding them. While EAP is often described as 'needs driven' in that it addresses the needs of students within the target context as a starting point for course design, critics claim this privileges institutional over individual need and ignores the rights of students to make choices and explore difference (Benesch, 2009). In the classroom, Huckin (2003) suggests that specific EAP can easily lead to a teacher-centred prescriptivism and an overly rigid focus on certain genres, forms and tasks at the expense of others. This straitjackets creativity, encourages a dull conformity to convention and a promotes a static, decontextualized pedagogy.

\section{Enter the dragon}

Clearly then, EAP is not everyone's cup of tea. Critics have been particularly hard on it, sometimes with good reason, while ignoring many alternative approaches, such as process writing methods familiar to undergraduates in US universities. Yet the field has not defended itself as robustly as it might, perhaps afraid of aligning itself with the reactionary views of those who occupy the unsavoury political corner it has been painted into. We should take issue with these claims, however, for without EAP too many students would be vulnerable to the challenging contexts in which they find themselves. The indifference of subject lecturers to literacy instruction means that EAP teachers are often the only support students have in understanding language and its relation to disciplinary practices (e.g. Hyland, 2013). It largely falls to EAP teachers to help students look at writing in a different way, seeing linguistic forms as not merely arbitrary, instrumental and autonomous, just 
something to 'get right', but as fundamental to disciplinary communication and to thought itself. There are, however, several issues here and it is worth considering each in turn.

\subsection{EAP and the corporatization of higher education}

First, it would be foolish to deny the detrimental impact the spread of English has had on other languages, some of which are now at risk of being relegated to less significant roles in an incipient global diglossia. Certainly EAP is firmly rooted in this development as without it there would be no demand for academic English instruction on the scale we now see. While not the cause of an expanding demand for its services, EAP has helped strengthened this expansion into countless courses and postgraduate places, helping to make it possible. Universities around the world are building their prestige, and income streams, by offering courses and degrees in the language, so that international students have become the economic lifeblood of many universities; a business worth over 11 billion pounds to the UK economy alone (Green, 2016). Similarly, the growth of an accountability culture that seeks to measure research "productivity" in terms of papers, and citations to those papers, has expanded EAP's role into English for Research Publication Purposes (ERPP).

EAP has perhaps been complacent in these developments, after all, it provides work and professional opportunities for teachers across the globe, yet it has not been entirely silent. Some of the fiercest critics of these developments are EAP teachers themselves (e.g. Pennycook, Benesch). But while EAP practitioners are not unaware of the context they work in, the realities of today's marketised higher education system means that those who design and deliver EAP courses are typically not in a position to influence the bigger institutional picture (e.g. Ding \& Bruce, 2017). Moreover, these developments in EAP are just one aspect of the process of corporatisation which has gripped higher education more widely. This is a new world with universities run by a professional administrative class earning CEOlevel salaries and with a focus on rankings, a view of students as customers, and a growing reliance on 
top-down administration and bean counting. This context creates considerable anxiety about job security and career opportunities for academics. In the US, for example, $50 \%$ of all appointments in American universities are now part-time and both part- and full-time non-tenure-track appointments have risen to $76 \%$ of the total (American Assn of University Professors, 2015).

In EAP itself courses are often squeezed of resources and students may be denied innovative teaching and learning opportunities as a result of university cost accounting measures (Marginson et al, 2010; Craig, 2010). Universities in the UK have also seen the potential profitability of 'commercial partnerships' with business interests to the extent of outsourcing their EAP programmes. Lucrative summer pre-sessional courses for international students are now often taught by teachers working for Kaplan or INTO with precarious job-security and no voice. As Hadley (2015) observes:

While before many (EAP teachers) were seen as culturally aware English language educators, often today they are viewed as linguistic service technicians tasked with repairing the broken language of international students, in order for them to be successfully 'processed' by the institution. Situated today within precarious work environments and saddled with heavy teaching loads, EAP educators have experienced not only a decline in agency, many are being reshaped and resocialized through discourse and practices that derive from the corporate world.

The corporatization of universities, the pressures on quality from 'for-profit' private providers, and the squeeze placed on short contract teachers who often work in them, mean that opportunities to challenge this model are limited and, indeed, may actually deteriorate further as the private sector presses the UK government to deregulate the sector and expand degree-awarding powers. In this environment, accusing marginalised EAP teachers of complicity in the consequences of the global spread of English might be likened to blaming coal miners for air pollution. 


\subsection{EAP and literacy education}

The charge that EAP is merely a skill-building exercise, occupying the low rent margins of the university and providing a support service to disciplines much like the library or statistical helpline, has always seemed overblown to me. Now it seems simply outdated. Although this view helps underpin the kinds of educational arrangements discussed above and is often expressed by faculty members (e.g. Hyland, 2013) and university administrators (Tardy \& Miller-Cochran, 2017), EAP has emerged to become an important branch of knowledge within applied linguistics, changing its character on the way. Originally, a purely practical field concerned with local contexts and the needs of particular students, we now have a better understanding of the complexities of needs, the interconnectedness of contexts, the conventions of text patterning and the relevance of social communities. Most importantly, we are beginning to see what these mean for teaching and learning.

EAP has become a much more theoretically grounded and research-informed enterprise in recent years, sitting at the intersections of applied linguistics, education and the sociology of scientific knowledge. Here it incorporates specialist expertise, focused practices, areas of inquiry, scholarly approaches and the paraphernalia of journals, monographs, conferences, and research centres. All the trappings, in fact, of a full-fledged educational practice.

At the core of EAP is a concern with developing the specific kinds of literacy which exist in higher education and which differ dramatically from those familiar to students from their homes, schools or workplaces. These ways of expressing meanings are by no means self-evident. They involve treating events as framed by cause and effect networks, disguising the source of modality of statements, foregrounding events rather than actors, and engaging with meanings defined by the text rather than the physical context. The inclusion of EAP in the curriculum attempts, therefore, to give students access to ways of knowing; to the discourses which have emerged to represent events, ideas and 
observations in the academy. It is also charged with engaging them in a critical understanding of the increasingly varied contexts and practices confront them. Nor is it the case, as it sometimes argued, that students need to build on general features of English before they learn these more academic ones. Second language acquisition research shows that students do not learn in this step-by-step fashion according to an external sequence imposed by a teacher but acquire features of the language as they need them (e.g. Ellis, 1994). Students may need to attend more to sentence-level features at lower proficiencies, but there is no need to ignore either discourse or discipline at any stage.

This is territory often assumed to be naturalised and self-evident; as non-contestable ways of participating in academic communities which are accessible to learners if they have a reasonable proficiency in English and are conscientious about reading their course texts. EAP steps into this terrain as a field of inquiry and instruction based on solid and evolving research foundations and a growing body of experience. EAP practitioners employ different streams of theory and research in their work. Central to this understanding is a focus on discourse rather than just language and how communication is embedded in social practices, disciplinary epistemologies and ideological beliefs. Spack's (1988) stereotype of the apprehensive language teacher, uncertain of the disciplinary knowledge of the students she is teaching and capable only of imparting a few study skills and ideas about time-management, has largely been replaced by a more confident figure.

A growing number of EAP professionals now go to class with a greater sense of their own expertise and more secure in the knowledge they are teaching the rhetoric of a disciplinary and not its content. Underpinning this belief is the support offered by corpus research and access to a literature offering a greater understanding of the structures and meanings of texts, the demands placed by academic contexts on communicative behaviours, and the pedagogic practices by which these behaviours can be developed. This is, of course, a more professionally challenging role for teachers and requires the 
jack-of-all-trades EAP practitioner to become a specialist in the discourses of particular disciplines. At the same time, this lifts the importance of the centres they work in and the field they teach. This additional professionalism obviously costs institutions more in attracting better qualified teachers and ensuring they are given appropriate professional development opportunities to research the demands of disciplinary study. The additional cost of this, however, is offset by more efficient, targeted, and motivating instruction, so that cost-effectiveness should be determined not just on the basis of cost but on the basis of effectiveness.

\subsection{EAP and disciplinary learning}

Related to the view that EAP lacks educational credentials, bur requiring a slightly different rebuttal, is the idea of a common core. This position is less critical of EAP itself, but suggests teachers should stick to teaching generic skills and language forms that are the same across most disciplines and which students can be taught once they've mastered the nuts and bolts of English grammar. On the face of it this seems a reasonable argument and in some cases, such as pre-sessional and IELTS preparatory courses, or in a freshman year before students chose their major, English for General Academic Purposes courses can have real value (e.g. Hyland, 2017). Essentially, however, these can only bridge the gap between the kinds of language students learn and use at school, which are typically often proficiency-focused personal essays, to the specific demands of disciplinary writing.

The challenge for most EAP teachers is to find ways of helping students from disciplines as distinct as Medicine, History and Electrical Engineering to meet the literacy challenges of achieving university success. A massive literature now shows that rhetorical choices vary enormously across disciplines because they express very different epistemological and social practices. This means that students learn their disciplines as they learn its discourses. Subject teachers, however, generally lack both the expertise and desire to teach literacy skills (Hyland, 2013), frequently believing these are self- 
evident and acquired by reading their course texts. Often faculty, especially those in the hard sciences, lack the means to conceptualise this literacy and the metalanguage to analyse and teach it, supposing it involves merely a more advanced proficiency. But faculty members themselves often disagree on what generic skills and commonalities should be in the university curriculum, with Krause's (2014) sample of 50 academics holding views which differed by discipline.

In fact, even if we wanted to restrict EAP to a general focus on advanced proficiency there are serious problems with identifying a 'common core' of language items. Certainly there are register-level features which characterize a great deal of academic discourse, particularly writing. Students are often encouraged to employ features such as nominalization, impersonalization, and lexical density, foregrounding disciplinary arguments and subject matter to suppress their personal interests and identities. They are asked to sacrifice concreteness and empathy, disguise the dynamic processes of change and instead discuss abstract concepts and relations, categorize, quantify, and evaluate according to the perspectives of their discipline. However, this is frequently done in different ways and to a different extent across the disciplines (Hyland, 2004).

In addition, as I mentioned in the last section, we now know a great deal about how disciplines use language, from the frequency and meanings of self-referring pronouns (Hyland, 2012) to the genres on which students are assessed (Nesi \& Gardner, 2012). The emergence of discipline-specific vocabulary lists, for example, such as Mudaraya (2006) for engineering, Valipouri and Nassaji (2013) for chemistry and Ha and Hyland (2017) for finance and accountancy, underpin how disciplines draw on different vocabularies to talk about the world. It would, therefore seem almost perverse not to employ the considerable knowledge we have of disciplinary variation in the service of teaching. The idea of professional communities, each with its own particular practices, genres, and communicative conventions, leads us towards a more specific role for EAP at the same time as a growing body of 
literature into how knowledge is socially constructed through disciplinary discourses, strengthens its theoretical underpinnings. This makes relevance more obvious to students, and therefore potentially more motivating by activating their often considerable subject-specific knowledge. It also ensures that students are not studying aspects of the language they do not need or that may be used differently in their own specific fields of study.

Taking specificity seriously challenges the idea that academic literacy is a single, overarching set of value-free rules and technical skills. It reveals variability and suggests to both students and faculty that the language needed in academic contexts is not merely an extension of everyday English. As a result of this, it becomes harder to see student difficulties as the result of a deficit of literacy skills which can be topped up through some intensive language classes. Engaging students in their studies and using the time we have with them most effectively leads us to specific varieties of academic discourse, and to the consequence that learning should take place within these varieties.

\subsection{EAP and the critical turn}

The final argument I want to address here is the view that EAP is a tool of institutional indoctrination, uncritically filling obedient students with disciplinary norms and ideologies. Undoubtedly the field owes much to Pennycook $(1997)$, Benesch $(1996,2001)$ and others for steering the critical turn in education towards EAP back in the 1990s and provoking teachers to engage with the wider consequences of their work. This has brought a much needed "spirit of reflexivity and interrogation" Benesch (2009: 81) to the profession and, I think, created greater self-awareness among practitioners. We now go into class in the knowledge that no pedagogical approach or teaching decision is entirely politically neutral. However, it remains uncertain what we should do with this knowledge. 
One problem for teachers is that many of the canonical texts in critical EAP and critical pedagogy more generally are too remote from everyday practice, favouring impenetrable jargon over classroom approaches, and therefore offering poor guides to pedagogy (e.g. Morgan, 2009). Harwood \& Hadley (2004, 365), for example, rebuke Critical EAP for failing "to offer pedagogical alternatives" or "readily implementable classroom episodes". This is not only unhelpful, but also sets up a divide between theorists and teachers: between those who think about the bigger picture and 'vulgar pragmatists' (Pennycook, 1997) who unreflectively work to fit students into subordinate roles. This division is likely to alienate teachers and hardly helps them to overcome the exclusionary practices of the academy. Nor is it helpful of critical EAP to position teachers as more-or-less willing servants of the machine while avoiding any serious critique of its own beliefs and practices. Critical discourses can, then, be perilously dogmatic and judgemental and, as McAllister (2016: 287) observes, “this potentially creates problems for EAP professionals who want to be reflective and politically engaged in their practice".

To its credit, Critical EAP has sought to offer ways forward for teachers through examples of classroom practice which attempt to make ideological elements of students' learning visible to them and "to create possibilities for social awareness and action" (Benesch, 1996, p. 735). Benesch, for example, sought to relate her class more closely to students' social worlds by discussing issues such as anorexia and domestic violence in her paired EAP/psychology class while Pessoa and Freitas (2012) describe a Brazilian course for teaching English through critical socio-political issues. This pedagogy, however, tends to underplay classroom power relations and sidesteps the possibility that students hold different views to the instructor. How do they express alternative views? Is a middle-ground compromise really possible in contexts where students come from backgrounds which discourage disagreement with teachers? This becomes a particularly charged issue when the teacher advocates taking political action such as Benesch (1996) encouraging her students to write letters to a political candidate opposing his 
stance on cutting educational spending or using her classes to resist military recruiters on campus (Benesch, 2010).

While these might be commendable aims, we have to bear in mind that students are not cultural dopes and often have strong convictions of their own. The "student consumer" of the $21^{\text {st }}$ century, relatively austere, career-focused and laden with debt, is keen to get what he or she has paid for. Moreover, the diversity of EAP teaching contexts means that many are underprivileged, migrants or refugees and bring to class experiences of deprivation or persecution that we can only imagine. So does the teacher always know best? This seems dogmatic and alienating while conveying an archaic view of teacher-student relations. The point is that we have to give learners credit for having their own views and avoid so-called 'empowering practices' that position them in the same passive and unequal relationship for which Critical pedagogy criticizes pragmatic pedagogy (e.g. Lather, 1992). This simply moves from one kind of prescriptivism to another rather than bringing democratic and reflexive practices to the classroom (Fenton-Smith, 2014). Indeed, Freedman (2007) argues that classrooms can never be democratic sites where all views are equal as the teacher's voice always carries a special authority.

I want to emphasise here that I'm not condemning EAP teachers who want to focus on controversial social themes, I do so myself. I am merely observing that we need to proceed with caution, affecting a neutrality we might not feel, providing time for voices we disagree with and showing respect for student voices which oppose out own. It all needs to be done with sensitivity and a perspective on pedagogy that values diversity and respects genuine interaction, not top-down truths delivered by an authority figure. Nor am I arguing that we cannot encourage students to question their discipline lecturers about the readings they set, the feedback they give or the assessment methods they use. As Johns (1997) pointed out 20 years ago, students should be asked to research their relevant academic discourse community and draw on their experiences with genres to both critique texts and better understand what they are getting 
into. This kind of investigation helps show the variations in the expectations they will encounter and may even, if well handled, involve faculty in the literacy development of their students, perhaps showing them that their expectations of student texts are inconsistent and perhaps unrealistic. Difference, then, is better understood and made relevant as students are encouraged to question diverse, local forms of knowledge.

\section{EAP Genre pedagogy, language choice and critique}

The dominant approach in EAP classrooms is the use of genre exemplars, often informed by evidence about language provided by corpora of target texts. It is this approach which is characterised by critics as unfairly imposing alien models of language on students by requiring conformity to target disciplinary practices and failing to challenge institutional discourses (e.g. Lillis, 2001; Jenkins, 2014; Turner, 2012). The assumption in much of the critical literature is that the use of exemplars in EAP involves little more than mimicking textual models, thus condemning students to dull conformity and passive acceptance of institutional norms and ideologies. It is a view which, incidentally, also condemns EAP (and genre teachers) as acting against the best interests of students by spoon-feeding them with conformity. But EAP is not a monolithic approach and exemplars are used in many different ways.

Clearly, the dangers of a static, decontextualized pedagogy are very real and doubtless there are classrooms around the world where imitation of exemplars is standard practice. It is certainly true that if inexperienced or unimaginative teachers fail to acknowledge variation they might apply what Freedman (1994:46) once called "a recipe theory of genre" where students simply join the dots from blank screen to $\mathrm{B}+$. But there is nothing inherently prescriptive or conforming in a genre approach. There is no reason why providing students with an understanding of discourse should be any more prescriptive than, say, providing them with a description of a clause, the parts of a sentence. Of course genres have a constraining power which places limits on the meaning options that are available to writers, but the genre does not 'dictate' that we write in a certain way or determine what we write, it enables choices to be 
made and facilitates expression. Choices are always made in a context of incentives and communicative purposes so they always have social consequences.

Genre pedagogies, at least in EAP classrooms, tend to lean on a sociocultural approach to communication, emphasising reception and the importance of appropriateness. Writing, and interaction more generally, is based on expectations, so the process of writing involves creating a text that the writer assumes the reader will recognise and expect, and the process of reading involves working out what the writer is trying to do. In other words, we assemble sense from a text by making connections to prior texts to anticipate the other's actions. Genres, then, are the common, interpersonal way disciplinary communities use to understand the world and each other. Acquiring competence in specialized discourses offers neophytes and outsiders access to those communities. Genre analysis therefore situates learning and encourages students to analytically engage with relevant texts - not to blindly follow models but to recognise variation, novelty and creativity within what is routine practice.

Exemplar texts are selected because they represent models of target performance which can support students' learning and they are used to make both constraints and choices more apparent. Used effectively they give students the chance to recognise and make choices, and for many learners this awareness of regularity and structure is not only facilitating, but also reassuring. Choice is made possible by constraint, by awareness of what options are conventionally available and what different choices mean to readers. So genres embody diversity and facilitate innovation, but innovation is only possible in the context of convention. This allows us to distinguish creativity from error, for example. As Bamgbose (1998) observes, the difference can only be determined with reference to the internal norms of the community: "How many people use the innovation? How widely dispersed is it? Who uses it? Where is the usage sanctioned? What is the attitude of users and non-users to it?" (ibid p3). Analysis and 
understanding of genres therefore not only provides educational access but also the means to evaluate and judge: the resources to critically understand the contexts in which genres are produced and used.

So while genre pedagogies may lend themselves to an uncritical reproduction of discipline, they also provide insights into the workings of the international academy for learners. Far from being a simple tool of conformity, they are an essential prerequisite for an informed understanding of the contingency of prestige discourses and a critical reappraisal of discipline. As Christie (1987: 30) argues: "Learning the genres of one's culture is both part of entering into it with understanding, and part of developing the necessary ability to change it". Systematic discussion of language choices helps students see written texts as constructs that can be discussed in precise and explicit ways which allows them to be analysed, criticised and deconstructed. Highlighting variability helps undermine a deficit view which sees writing difficulties as learner weaknesses and which misrepresents writing as a universal, naturalised and noncontestable way of participating in communities. It is, moreover, absurd to think that large and influential international discourse communities are unable to accommodate diversity and disciplinary genres are not as rigid as the critics sometimes believe (Hyland, 2010; Tribble, 2017).

\section{Some final thoughts}

Reaching the end of this paper, I realise that while I set out to defend EAP from its detractors I may be guilty of sounding rather celebratory and uncritical. I did not plan to write a triumphalist account of the field and, indeed, see a lot wrong with it. EAP is far from the finished article and criticism is justified. The field continues to lack clout in terms of influential professors and a cohort of academic appointments in universities and has so far failed to establish a strong scholarship of teaching (Bass, 1999). The problematization of pedagogy is still not a matter of regular communal discourse in the field and often practitioners lack time for professional development and discussion of teaching issues. Nor have we distinguished ourselves in understanding how students experience their lives, their studies and 
their disciplines while privileging text above practice can sometimes lead us to treat language, and in particular writing, as primarily a linguistic, and perhaps even an autonomous, object rather than something which is socially embedded in particular lives, disciplines and contexts.

EAP has also been an easy target for universities wishing to raise money or cut costs as we have failed to establish the value of our work and the status of our profession. In part EAP units have brought this on themselves in their willingness to work for rather than with subject specialists. Teachers have, in the past, too readily adopted a support role to departments rather than developing and then asserting their own independent subject knowledge and skills. As this paper has reminded us, EAP has also been an easy target for critics of various hues. This may underline EAP's weaknesses and failures in the areas I have discussed above, but I hope to have at least planted some doubt about these arguments: how the case against EAP for pushing a corporate, expansionist agenda aims at the wrong target; that the charge of outsider amateurism has been superseded by the insights afforded by corpora; that the view of EAP having no content or educational value is trumped by the effectiveness of specialist courses; and that critical EAP's accusations of ideological collusion and normative brainwashing fail to look beyond a one dimensional stereotype.

We might also note that similar charges could be levelled at most other pedagogies, including those which are less effective than EAP in providing students with access to powerful genres. As I have suggested, learning about genres that have accumulated cultural capital does not rule out critical analysis but provides an essential foundation for it. We would also be remiss in failing to ask for evidence which documents any significant impact that critical approaches have had on classroom teaching. Despite the genuinely important insights and useful correctives that critics such as Academic Literacies, English as a Lingua Franca and Critical EAP writers have offered, they have not yet made a significant contribution to the development of academic writing or EAP pedagogy. But while they have 
not resolved issues by providing alternatives to EAP instruction, they have raised important questions which have encouraged practitioner reflection and strengthened professional practice.

The process of engaging with critical perspectives is clearly beneficial and several authors have encouraged a "best of both worlds" accommodation (e.g. Tribble \& Wingate 2013) or a "Critical Pragmatic EAP" (Harwood \& Hadley, 2004). Even Pennycook’s (1997) opening salvo offered a choice between "vulgar and critical pragmatism". Despite the tendency towards grand theory, dogmatism and practitioner condescension, EAP's critics have made a valuable contribution to the field in raising awareness of what lies behind our classroom decisions, particularly how we might incorporate greater awareness of choice in academic writing and what those choices mean. Armed with evidence of language use from corpora, we can make principled decisions about which features of target genres are essential to disciplinary communication and which are less so. In this way we have a principled, informed, and risk-aware basis for advising students which discourse conventions can be flouted (Clark, 1992) and which it might be best to observe.

So, overall, I think these criticisms have contributed positively to the different ways that EAP tackles its responsibilities and seeks to engage learners in understanding the increasingly varied contexts and practices of academic communication. They have helped practitioners become more conscious of their role and the conflicted teaching contexts in which they work. We recognize that our main goal is the enablement of student success in their fields of study, but that this has a political dimension which has consequences for how they see themselves and their futures. While EAP maintains a firm commitment to a sociocultural framework and the importance of the recipient design of texts, we also need to recognise everyday realities. Practitioners ply their trade in multiple and varied sites across the globe which allow more or less flexibility and opportunities to experiment and explore possibilities with 
students. Ultimately it is these local contexts, rather than universal narratives, which define what EAP is, how it is taught, and the potential it has to improve the lives of those who study it.

\section{References}

American Assn of University Professors (2015). Background Facts on Contingent Faculty. https://www.aaup.org/issues/contingency/background-facts [accessed 22 May 2017]

Ammon, U. \& McConnell, G. 2002. English as an Academic Language in Europe. Frankfurt: Peter Lang.

Bamgbose, A. (1998). Torn between the norms: innovations in World Englishes. 17 (1) 1-14

Bass, R. (1999). 'The Scholarship of Teaching: What's the problem?', Inventio, 1 (1) https://my.vanderbilt.edu/sot1/files/2013/08/Bass-Problem1.pdf [accessed 21 May, 2017]

Benesch, S. (2001). Critical English for academic purposes: Theory, politics and practice. London \& New York: Routledge.

Benesch, S. (2009). Theorizing and practicing critical English for academic purposes. Journal of English for Academic Purposes., 8, 81e85.

Benesch, S. (2010). 'Critical Praxis as Materials Development: Responding to Military Recruitment on a U.S. Campus'. In N. Harwood (ed) English Language Teaching Materials. Theory and Practice. Cambridge: Cambridge University Press

Björk, B-C., Roos, A. \& Lauri, M. (2009). Scientific journal publishing: yearly volume and open access availability. Information Research, 14(1). http://InformationR.net/ir/14-1/paper391.html]

Bloor, M., \& Bloor, T. (1986). Language for Specific Purposes: Practice and theory. In CLCS Occasional Papers. Dublin: Centre for Language \& Communication Studies, Trinity College.

Bordons, M \& Gomez, I. (2004). Towards a single language in science? A Spanish view. Serials. 17 (2): 189-195. 
Christie, F. (1987). Genres as choice. in I. Reid The place of genre in learning: current debates (pp. 2234). Deakin, Australia: Deakin University Press.

Clark, R. (1992). Principles and practice of CLA in the classroom. In N. Fairclough (Ed.), Critical language awareness (pp. 117-140). London: Longman.

Craig, N. (2010). Students from abroad treated like cash cows. The Melbourne Age http://www.theage.com.au/national/students-from-abroad-treated-like-cash-cows-20100522w31k.html (accessed 22 May 2017).

Ding, A. \& Bruce, I. (2017). The English for Academic Purposes Practitioner: Operating on the Edge of Academia. Basingstoke: Palgrave.

Edge, J. (2004). 'Of Displacive and Augmentative Discourse, Old Doubts and New Enemies'. TESOL Quarterly 38/4: 717-721.

Ellis, R. 1994. The study of second language acquisition. Oxford: Oxford University Press.

Fenton-Smith, B. (2014). The place of Benesch's critical English for academic purposes in the current practice of academic language and learning. Journal of Academic Language \& Learning. 8(3) A23-A33.

Fox, H. (1994). Listening to the world: Cultural issues in academic writing. Urbana, Illinois: National Council of Teachers of English

Freedman, A. (1994). "Do as I say?": the relationship between teaching and learning new genres. In A. Freedman \& P. Medway (eds.), Genre and the new rhetoric (pp. 191-210). London: Taylor \& Francis.

Freedman, E. B. (2007). 'Is Teaching for Social Justice Undemocratic?' Harvard Educational Review, 77(4), 442-473.

Giannoni, D.S. (2008). Medical writing at the periphery: The case of Italian journal editorials. Journal of English for Academic Purposes. 7 (2): 97-107 
Green, M. (2016). Boom time for UK universities as fee income encourages expansion. Financial Times April 28, 2016. https://www.ft.com/content/49b1ef76-0c5f-11e6-9456-444ab5211a2f

Ha, A \& Hyland, K, (2017) What is technicality? A Technicality Analysis Model for EAP vocabulary. Journal of English for Academic Purposes.

Hadley, G. (2015). English for Academic Purposes in Neoliberal Universities: A Critical Grounded Theory. London: Springer.

Harwood, N., \& Hadley, G. (2004). Demystifying institutional practices: Critical pragmatism and the teaching of academic writing. English for Specific Purposes, 23, 355-377.

Huckin, T. (2003). Specificity in LSP. Iberica 5: 3-17.

Hutchison, T. \& Waters, A. (1987) English for Specific Purposes. Cambridge: CUP.

Hyland, K. (2004) Disciplinary discourses: social interactions in academic writing. Ann Arbor, MI: University of Michigan Press.

Hyland, K. (2006). Representing readers in writing: student and expert practices. Linguistics and Education 16: 363-377.

Hyland, K. (2010). Community and individuality: performing identity in Applied Linguistics. Written Communication. 27 (2): 159-188.

Hyland, K. (2012) Disciplinary identities. Cambridge: CUP

Hyland, K. (2013). Faculty feedback: perceptions and practices in L2 disciplinary writing. Journal of Second Language Writing 22: 240-253.

Hyland, K. (2015). Academic publishing: Issues and challenges in the construction of knowledge. Oxford: OUP.

Hyland, K. (2017). English in the discipline: Language provision in Hong Kong's new university curriculum. In Eun Sung Park (ed.) English education at the tertiary level in Asia. New York: Routledge. pp 27-45 
Jenkins, J. (2014). English as a Lingua Franca in the International University: The Politics of Academic English Language Policy. Abingdon: Routledge.

Johns, A.M. (1997). Text, role and context: developing academic literacies. Cambridge: Cambridge University Press.

Krashen, S. (2011). Academic proficiency (language and content) and the role of strategies. TESOL Journal 2(4): 381-393.

Krause, K. L. D. (2014). Challenging perspectives on learning and teaching in the disciplines: the academic voice. Studies in Higher Education 39(1): 2-19.

Kumaravadivelu, B. (2006). 'Dangerous Liaison: Globalization, Empire and TESOL', in J. Edge (ed) (R)elocating TESOL in an Age of Empire. Houndsmill: Palgrave Macmillan.

Lather, P. (1992). Post-critical pedagogies: a feminist reading. In C. Luke \& J. M. Gore (Eds.), Feminisms and critical pedagogy (pp. 120-137). New York: Routledge.

Lea, M. R., \& Street, B. V. (1998). Student writing in higher education: An academic literacies approach. Studies in Higher Education, 23/2, 157-172

Li, Y-Y. \& Flowerdew, J. (2009). English or Chinese? The trade-off between local and international publication among Chinese academics in the humanities and social sciences. Journal of Second Language Writing, 18(1), 17-29.

Lillis, T. (2001) Student writing: access, regulation, desire. London: Routledge.

Macallister, C.J. (2016). Critical perspectives. IN Hyland, K. \& Shaw, P. (eds.) The Routledge handbook of EAP. London: Routledge: pp283-293.

Marginson, S., Nyland, C., Sawir, E., \& Forbes-Mewett, H. (2010). International student security. Cambridge: Cambridge University Press

Morgan, B., \& Ramanathan, V. (2005). Critical perspectives and language education: Global and local perspectives. Annual Review of Applied Linguistics, 25, 151e169. 
Meneghini, R. \& Packer, A.L. (2007). Is there science beyond English? Initiatives to increase the quality and visibility of non-English publications might help to break down language barriers in scientific communication. EMBO Reports. 8(2): 112-116.

Morgan, B. (2009). Fostering transformative practitioners for critical EAP: Possibilities and challenges. Journal of English for Academic Purposes, 8, 86-99.

Mudraya, O. (2006). Engineering English: A lexical frequency instructional model. English for Specific Purposes, 25(2), 235-256.

Nesi, H. \& Gardner, S. (2012). Genres across the disciplines: student writing in higher education. Cambridge: Cambridge University Press.

Paltridge, B., Starfield, S. \& Tardy, C. (2016) Ethnographic Perspectives on Academic Writing. Oxford: OUP.

Pennycook, A. (1997). Vulgar pragmatism, critical pragmatism, and EAP. English for Specific Purposes, 16(4), 253-69.

Pennycook, A.(2001). Critical applied linguistics: A critical introduction. Mahwah, NJ: Lawrence Earlbaum.

Pessoa, R. \& Freitas, M. (2012). Challenges in Critical Language Teaching. TESOL Quarterly. 46 (4): $753-776$

Raimes, A. (1991) Instructional balance: from theories to practices in the teaching of writing. In Alatis, J. (ed.) Georgetown University roundtable on language and linguistic. Washington DC: Georgetown University Press.

Shen, Fan (1989). The classroom and the wider culture: identity as a key to learning English composition. College Composition and Communication, 40(4), 459-466.

Spack, R. (1988). Initiating ESL students into the academic discourse community: how far should we go? TESOL Quarterly, 22(1), 29-52.

Swales, J. (1997). "English as tyrannosaurus rex". World Englishes 16: 373-382. 
Swales, J. (1998). Other Floors, Other Voices: A Textography of a Small University Building. Mahwah, NJ: Erlbaum.

Tardy, C. \& Miller-Cochran, S. ( 2017). Administrative structures and support for international L2 writers: a heuristic for WPAs. In S. Rose \& I. Weiser (eds.) The internationalisation of US writing programs. Utah State University Press.

Tribble, C. (2017). ELFA vs genre: a new paradigm war in EAP writing instruction? Journal of English for Academic Purposes 25: 30-44.

Tribble, C., \& Wingate, U. (2013). From text to corpus e A genre-based approach to academic literacy instruction. System, 41/1(2), 307-321.

Turner, J. (2012). Academic literacies: Providing a space for the socio-political dynamics of EAP. Journal of English for Academic Purposes, 11, 17-25

Valipouri, L., \& Nassaji, H. (2013). A corpus-based study of academic vocabulary in chemistry research articles. Journal of English for Academic Purposes, 12, (248-263).

Widdowson, H. (1983). Learning purpose and language use. Oxford: Oxford University Press. 